\title{
THE EFFECTS OF USING BLOG-ASSISTED LANGUAGE LEARNING (BALL) IN IMPROVING NON-NATIVE STUDENTS' ENGLISH WRITING SKILL IN HIGHER EDUCATION; DOES IT WORK?
}

\author{
Asnawi Muslem (D, Saiful Marhaban $1 D$, Hendra Heriansyah ${ }^{D}$, Rizki Putra Utama $i D$ \\ Universitas Syiah Kuala (Indonesia) \\ drasnawi@unsyiah.ac.id,saiful22@unsyiah.ac.id, hendrisa@unsyiah.ac.id,tamacage66@yahoo.co.id
}

Received April 2021

Accepted August 2021

\begin{abstract}
Improving students' writing skill at higher education level in Indonesia through using technology becomes a primary attention given by the researchers. Blog-Assisted Language Learning (BALL) is one of the best alternative medium of improving students' writing skill. This BALL is never used by the lecturers who are teaching writing skill to students at State Islamic University of Ar-Raniry, Banda Aceh. Therefore, the objectives of this study are to investigate if there is a significant different between students who are taught by using Bog-Assisted Language Learning (BALL) and without in term of students' writing skill at State Islamic University of Ar-Raniry, Banda Aceh, Indonesia. Additionally, this study also investigates the students' response toward the use of BALL in teaching and learning process of writing skill. The study involved 40 third year English students of the State Islamic University of Ar-Raniry, Banda Aceh. The study employed quantitative method in collecting the data through pre-and post-writing tests and a set of questionnaire for both groups; experiment and control. The data collected were analysed using descriptive statistic. The results showed that the use of BALL in teaching writing improved significantly rather than students who were taught without using BALL. In addition, the majority of students' response toward the implementation of BALL in teaching writing skill were positive. Therefore, the use of BALL in teaching and learning writing at English Department students of State Islamic University of Ar-Raniry can improve students' writing skill.
\end{abstract}

Keywords - BALL, Writing skill, Non-native, Higher education students.

\section{To cite this article:}

Muslem, A., Marhaban, S., Heriansyah, H., Utama, R.P. (2022). The effects of using blog-assisted language learning (BALL) in improving non-native students' English writing skill in higher education; does it work?. Journal of Technology and Science Education, 12(1), 21-32. https://doi.org/10.3926/jotse.1303

\section{Introduction}

In this $21^{\text {st }}$ century, the competence to communicate in English is essential. Language teachers or lecturers especially English language are trying to find the most effective method and strategy to polish their students' English competence. They have shifted their teaching methods significantly from traditional one to using technology tools to enhance students' performance in mastering English language skills. Various 
studies have been done for the purpose of improving quality of education and pedagogy among students and teachers around the world and more specifically the use of technology in teaching and learning for English language skills to meet the countries' demand and expectation (Muslem \& Abbas, 2017; Qader \& Yalcin-Arslan, 2019; Danaher \& Schoepp, 2020; Aditya, 2021). The ability to communicate in English through wrtitten form is very essential. The ability to write in English is not an easy task for non-native students. Many aspects that should be mastered well by students when writing an essay in English. For instance, a student should how to write with no misspelling, know how to use dot, question mark, capital letter, and etc. Various methods and techniques have been used to improve students' writing skill such as, cooperative learning, think pair share, contextual teaching and learning, communicative language teaching, group discussion (Satriani, Emilia, Gunawan, 2012; Muslem \& Abbas, 2017). However, students' ability to write smoothly and correctly still remains the problem for students.

The use of technology devices in teaching and learning process has proved that it helps teachers and students to improve their quality (Alfarwan, 2019). Various benefits can be obtained by using media technology in the teaching and learning process, especially English language as a foreign language in non native country like Indonesia. Lecturers at university need to master knowledge and skills on how to use technology for the sake of teaching English as a foreign language (Oliver \& Goerke, 2007; Alfarwan, 2019). In addition, the use of technology in the classroom for teaching English does not only improve students language skills but also improve their motivation (Fatimah \& Santiana, 2017). One of the best medium to use in teaching and learning English is Blog-assisted Language Learning (BALL), replacing the older idea of the computer just as a surrogate teacher (Ward, 2004; Dashtestani, 2018). This media of learning has never been used in teaching English especially writing skill at State Islamic University, Ar-Raniry, Banda Aceh. Lecturers at the university tends to use traditional methods to teach students' writing. Ward (2004) says Blog-Assisted Language Learning is a series of activities which involves Blogging activities, comments, and peer feedbacks. Students are required to write some entries or posts in which later on be responded by readers either by the classmates themselves or by public readers. Peer feedbacks are used to facilitate students correcting each other's writing in order to make them aware of their own mistake.

Many kinds of technology have been used in the teaching and learning English either at school or university level such as computer, youtube, video, tape recorder, power point, and mobile phone. A few studies have been conducted to improve students' writing skill at university level in Indonesia through Blog-Assisted Language Learning (Wu, 2005; Chinnery, 2006; Chhabra \& Sharma, 2011; Aditya, 2021). However, in oversea many foreign educators have implemented this user-friendly technology to classroom instruction and language learning in general (Lankshear \& Knobel, 2003). This blog is not intended originally constructed for use in language education, blogs have formidable potentials as a meaningful tool for the teaching of EFL writing class (Wu, 2005). Blog uses may offer instructors a helpful tool for teaching writing at the tertiary level in Teaching English as a Foreign Language (TEFL) classrooms (Arslan \& Şahin-Kız1l, 2010; Ahluwalia, Gupta \& Aggarwal, 2011). Therefore, the objectives of this current study are to find out the answers of the following research questions:

1. Is there any significant difference between students who are taught by using blog-assisted language learning (BALL) and without the use of BALL in term of students' writing skill at State Islamic University of Ar-Raniry Banda Aceh, Indonesia?

2. How are the students' response toward the use of BALL in the teaching and learning process?

\section{Learning and Technology}

Learning and Technology today are a good combination when it is done correctly (Chinnery, 2006). It is a general knowledge to realise that technology can give good and bad impact to teaching and learning. Smith and Mainka (2010) state that the implementation of technology has started since 1950s. It first began with mechanical teaching machines which later on continued with computer-based instruction in the early 1980s. Recently, internet or a thing that usually called WWW (World Wide Web) comes to humanity. Along 
with mobile technology, the implementation of technology in teaching and learning has given a very promising result. In line with this statement, technology such as internet can be used to learn and improve students' language learning as well as the resources of learning for everyone, anytime, and everywhere as they like without going to class to learn it (Honarzd \& Rassaei, 2019).

It still feels unbelievable that teacher and student now can discuss lessons through social media or email whereas years ago people have to meet face to face to do that. A teacher now can handle large class easily if he knows how to work with email properly. Teachers used to deal with same questions from students repeatedly. But by the help of email, teacher can easily answer students' questions without having to be overwhelmed. Peer working and inquiry-based learning are also promising methods that include technology. Students can do some investigation on some issues, gathering information from internet and submitting the report through online media. Collaboration between students are also become easier. They can communicate and finish their task through an online group made in social media such as Facebook or other platform such as blog (Smith \& Mainka, 2010). Things mentioned above are all the examples on how the development of technology has led us to the better condition where the teaching and learning process has been way better.

\section{Writing Expository Text}

Expository text is the specific lesson that the researcher utilized in this research. To understand more about the expository text, the researcher elaborated some information about Expository text. Expository text is a text structure that include a few structures such as generalization, classification, cause and effect, sequence, compare and contrast and enumeration (Cook \& Mayer, 1988). It is a written discourse that is used most likely to explain or inform the reader about some information. (Information about Expository Writing, 2018). Expository text is meant for readers that don't have any previous background about the information that is discussed. Thus, it is essential for the writer of expository text to write the text more clearly.

Based on Ball (1992), there are five expository text structures. The first one is description. In description pattern, the writer is required to describe a topic by putting into the list the characteristics, features, attributes and examples. A few signaling words used in this pattern are for instance, such as, including, and so on. In the sequence pattern, the author of an expository text is needed to list items or events within chronological order. This text can be written both in explicit or implicit way. Some of the cue words in this type of pattern are first, second, next, finally and more. In expository text, there is also comparison pattern. The writer who write about comparison must present two information that are being compared in details. The details of the information can be any events information, concepts, theories and more. Some signaling words used in this pattern are however, nevertheless, on the other hand and so on. Cause and effect is also another pattern used in expository writing. In this pattern, the writer is encouraged to present facts from the cause and the result of the cause. The writer of cause and effect mostly used some signaling words such as a result, therefore, consequently and so on. Last version of expository text is problem and solution. Not much different from cause and effect, the writer needs to present the problem and the solution in the article. Signaling words such as problem is, because, if/then are used in this type of pattern.

\section{The Use of Blog-Assisted Language Learning in Teaching Writing}

Even though Blog-Assisted Language Learning just become a recent phenomenon, it has gained so much interest from writing researchers, teachers and course designers (Lin, 2013, p.130). The presence of Blog has given more space to writers to share new ideas including materials and articles in order to be reached out by audience (Said, Yunus, Doring, Asmi, Aqilah \& Li 2013: page 95). This experience can be used to motivate students in learning writing. Students are immersed into bloggers' situation in which they require to share and update interesting information within their own blog (Said et al., 2013). For some English teachers and lecturers Blogs may be still strange to use in the teaching and learning EFL process in Indonesia. Through Blog teachers and students can express their thought in written form (Goldstein, 
2009; Hourigan \& Murray, 2010; Getgood, 2010; Gardner \& Birley, 2012; Sidek \& Yunus, 2012). What is blog? A blog (shortening of "weblog") is an online journal or informational website displaying information in the reverse chronological order, with latest posts appearing first. It is a platform where a writer or even a group of writers share their views on an individual subject. Due to blog features that easy to use interface, frequent text update, and interactive comment field, most teachers and lecturers applied their blogs to reading and writing classes (Oravec, 2002; Wilder \& Merritt, 2004; Pinkman, 2005; Richardson, 2009; Sun, 2009). Based on Lin, Groom and Lin (2013) phenomenological analysis, there are several important functions of Blogging in teaching writing:

\section{a) Blogging as Journaling}

The use of BALL in the classroom was perceived as a way of learning writing by doing a journaling. Journaling becomes a part of blogging activity that can improve writing of the bloggers (Lin et al., 2013). Because Journaling requires the bloggers to update regularly the entry on their websites and the repetition made them become used to the activity.

\section{b) Blogging as a fresh, novel, and convenient platform}

Besides as journaling, Blog is also thought as a fresh and convenient platform. The presence of tools in writing article such as bold, underline, adding pictures, heading 1, heading 2 and so on, increase the ease of Blog usage. In his research, Lin et al. (2013) says that:

...the integration of new technology into the learning setting left them perceiving the experience differently from the conventional, non-online approaches that they had experienced previously in their school careers. For example, Gloria reflected in her final journal entry that "this experience is so new and cool to me," a sentiment with which Cindy also agreed. To many others, BALL was perceived as novel because their entries were published in an online public setting...

In addition, Lin et al. (2013) also added that the possibility to edit the posted entry was considered very convenient.

...Isaac liked the fact that he could "take the advantage of retrieving past work", while Danny regarded the ability to access peer journals as "convenient." The underlying component of this sense of convenience, however, mostly related to the fact that they were able to submit assignments online, from any location, and in their own time. As Cindy remarked, "this is very convenient because I don't need to worry about forgetting to bring the material or rushing to school to hand in assignments to the office." A further perceived advantage was pointed out by Olivia: "blogs are convenient because I can access material or review your [referring to the teacher] notes any time I like." It is largely because of this general sense of convenience that students expressed approval at the idea of BALL being used in future courses...

\section{c) Blogging as a Form of Online Mimicry Learning}

The BALL experience helped students to write in English language more effectively. The use of peer feedbacks encouraged the students to take more concerns on the grammar and word choice aspect (Lin et al., 2013). Some essential aspects and steps have been mentioned previously. Those elements sometimes become challenges to students. Some students may have difficulties to build a good paragraph body and some others may possess some obstacles in making sentences coherent. In handling the challenges, the teacher should provide good explanation and good amount of time to do the writing process. It cannot be neglected that writing is an ongoing process as what Barnett (1989) has stated beforehand.

\section{Methodology}

In order to prove if the use of BALL enhances the students' writing skill, an experimental design was employed. Quasi-experiment was conducted to evaluate the effectiveness of a treatment of an educational intervention. In this case, two classes of students were selected; one class was given treatment using 
Blog-Assisted Language Learning in the teaching and learning process to enhance students' writing skill and another class was assigned as control group which was not given the same treatment as in experimental class. The participants of this study were two classes of English Education Department of State Islamic University of Ar-Raniry, Banda Aceh, Indonesia. The participants were not randomly assigned to conditions, however, the resulting groups were likely to be dissimilar in some ways. For this reason, authors consider them to be nonequivalent which mean then, is a between-subjects design in which participants have not been randomly assigned to conditions. Each class consisted of 20 students. So, all the sample of this current study consisted of 40 students. Before conducting the treatment to experimental group, the pre-test was given to both groups in order to know the students' basic writing skill. After that, the treatment was conducted. The authors used both pretest and postest to measure the score before and after the treatment. There were two groups that take parts in the experimental process. Experimental group students was taught by using BALL and the control group students was taught by using non BALL. The scores of both groups were compared to see if there was any significant difference between the two groups. The data collected were analysed quantitatively by using statistical analysis.

\section{Results}

$R Q$ 1: Is there any significant difference between students who are tanght by using blog-assisted language learning (BALL) and without the use of BALL in term of students' writing skill at State Islamic University of Ar-Raniry Banda Aceh, Indonesia?

The use of Blog-Assisted Language Learning in Teaching Writing skill was significantly improved students' performance in writing. It was proved by the $t_{\text {trst }}>t_{\text {table }}(2.52>2.04)$ in which there was a significant difference between students' who are taught by using BALL and those who were not using BALL methods in teaching and learning writing. Thus, the hypothesis of this study was accepted. There was a significant improvement of students' writing skill after they were taught by using BALL. The following table showed the scores of experimental class of pre and posttest.

\begin{tabular}{|c|r|r|}
\hline \multicolumn{3}{|c|}{ Experimental Class Mean Score } \\
\hline No & Pre-test & Post-test \\
\hline 1 & 71.6 & 79 \\
\hline 2 & 65.8 & 82 \\
\hline 3 & 73.2 & 82.4 \\
\hline 4 & 82.2 & 82 \\
\hline 5 & 74.4 & 80.8 \\
\hline 6 & 72.8 & 75.6 \\
\hline 7 & 65.2 & 73.8 \\
\hline 8 & 61.4 & 84.2 \\
\hline 9 & 66.8 & 87.2 \\
\hline 10 & 73.8 & 76.4 \\
\hline 11 & 78.4 & 79.6 \\
\hline 12 & 77.8 & 78.4 \\
\hline 13 & 63.4 & 79.8 \\
\hline 14 & 80.6 & 82.8 \\
\hline 15 & 69.6 & 74 \\
\hline 16 & 82.4 & 83.4 \\
\hline 17 & 73.8 & 76.4 \\
\hline 18 & 60 & 84.8 \\
\hline 19 & 76.2 & 79.4 \\
\hline 20 & 61.2 & 84.4 \\
\hline
\end{tabular}

Table 1. The scores of the Experimental Class on Pre-test and Post-test 
Table 1 above displays the scored of pre-test and post-test for the experimental class before and after the application of Blog-Assisted Language Learning. It shows that only one student gets the lowest and the highest scores in which 60 and 82.4. Meanwhile, there is only a student who get 73.8 as the lowest score in the post-test and 87.2 as the highest score in the posttest. It can be concluded that there is a significant improvement between pre-test and posttest scores in the experimental group.

\begin{tabular}{|c|r|r|}
\hline \multicolumn{3}{|c|}{ Control Class Mean Score } \\
\hline No & Pre-test & Post-test \\
\hline 1 & 72 & 72.4 \\
\hline 2 & 68 & 69.4 \\
\hline 3 & 72.6 & 72.6 \\
\hline 4 & 83 & 84 \\
\hline 5 & 75.4 & 76 \\
\hline 6 & 72.2 & 72.8 \\
\hline 7 & 68.8 & 69 \\
\hline 8 & 69.2 & 70.2 \\
\hline 9 & 73 & 73.8 \\
\hline 10 & 74 & 74.8 \\
\hline 11 & 78.4 & 80.2 \\
\hline 12 & 73.6 & 73.8 \\
\hline 13 & 70.8 & 71.8 \\
\hline 14 & 78.6 & 78.8 \\
\hline 15 & 77.4 & 79 \\
\hline 16 & 78 & 78.8 \\
\hline 17 & 75.2 & 76 \\
\hline 18 & 70.4 & 71.8 \\
\hline 19 & 69 & 70.2 \\
\hline 20 & 66.4 & 68 \\
\hline 12 & 6 & \\
\hline
\end{tabular}

Table 2. The Score of the Control Class on Pre-test and Post-test

Table 2 reports the raw score of the pre-test and posttest in the control class that uses conventional method of teaching. It shows that only one student who get the lowest and the highest scores in pre-test in control group that is 66.4 and 84 . Thus, it can be concluded that there is no significant improvement of students' writing in the control class by using conventional method. Referring to the two scores of the two groups; experimental and control shows in Table 1 and 2, then the authors report the mean scores of both groups as showed in Table 3 below.

\begin{tabular}{|c|l|r|r|}
\hline Groups & N & Mean & \multicolumn{1}{|c|}{ Std. Deviation } \\
\hline Experimental Group - Post-test & 20 & 80.32 & 6.8362 \\
Control Group - Post-test & 20 & 74.17 & 8.3759 \\
\hline
\end{tabular}

Table 3. The Mean and Standard Deviation of the Post-test of Experimental and Control Groups

The Table 3 above shows the result of mean score for both two groups posttests in each experimental and control groups. It shows the mean score for experimental groups is 80.32 and standard deviation is 6.8362. Meanwhile, the mean score of the control group is 74.17 and standard deviation is 8.3759 . Furthermore, the results of both post-test score analyzed using independent sample t-test to see the differences between the two groups. 


\begin{tabular}{|c|c|c|c|}
\hline Dep. Variables & \multicolumn{3}{|c|}{ t-test for Equality of Means } \\
\hline & $\mathrm{t}$ & $\mathrm{df}$ & Sig. (2-tailed) \\
Post-test Groups & -2.528 & 38 & 0.0186 \\
\hline
\end{tabular}

Table 4. Independent Sample T-Test Analysis of the Post-test Scores of the Experimental and Control Groups

Table 4 above shows that the value of Sig. (2-tailed) is less than $0.05(0.0186<0.05)$ which means that $H_{a}$ is accepted. Therefore, the alternative hypothesis of this study is accpeted and reject the null hypothesis. It means that there is a significant difference achievment between experimental and control groups in learning writing by using Blog-Assisted Language Learning method. In short, it can be concluded that the use of Blog-Assisted Language Learning improves students' writing skill at the English Department of State Islamic University of Ar-Raniry, Banda Aceh, Indonesia.

\section{RQ 2: How are the students' response toward the use of BALL in the teaching and learning process?}

Referring to the Research Question 2, it can be reported that the students give positive response to the use of Blog-Assisted Language Learning in teaching and learning writing. For more detail about the students' response to the use of BALL in the teaching and learning can be seen in the following figures.

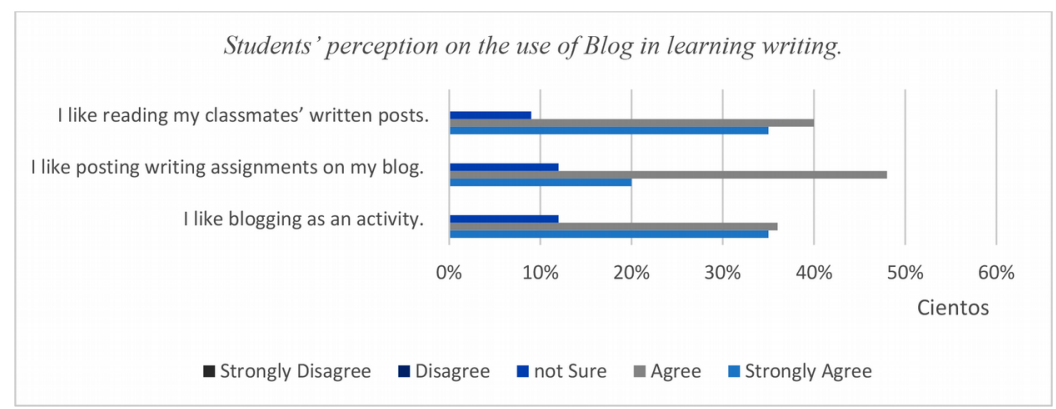

Figure 1. Students' perception on the use of Blog in learning writing

The Figure 1 reports students' perception on the use of Blog in learning writing that covers three statements as shown in the figure. It shows that students have positive perceptions towards the use of Blog-Assisted Language Learning in teaching writing. It is proven from their answers provided on the figure above where $35.00 \%$ students strongly agreed and $36.00 \%$ agreed that blogging could be a learning activity. However, there were $12.00 \%$ students that were not sure about the statement number 1 . Students also believe that blog can be a writing assignment tool. $20.00 \%$ of the students strongly agreed to the statement, $48.00 \%$ of them agreed to the statement, and only $12.00 \%$ of them that were not sure with the statement number 2. In addition, students agreed that reading other students' blog post were a good activity. $35.00 \%$ of the students strongly agreed about the statement, $40.00 \%$ of them agreed to the statement, and only $9.00 \%$ of them that were not sure about the statement number 1 .

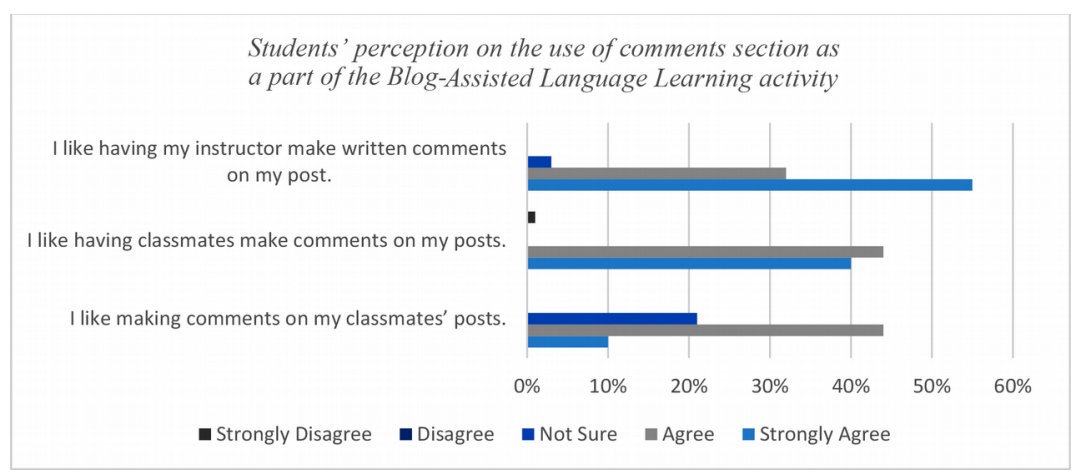

Figure 2. Students' perception on the use of comments section as a part of the Blog-Assisted Language Learning activity 
Based on the figure above, the research found that students believe there was a positive impact from having the instructor writing comments on their blog posts. Figure 2 showed that $55.00 \%$ strongly agreed, $32.00 \%$ agreed, and only $3.00 \%$ were not sure about the statement. Students also believe that classmates' comments left on their blog posts were found interesting and encouraging. There were $55.00 \%$ of the students strongly agreed, $32.00 \%$ agreed, and only $1.00 \%$ strongly disagreed to the statement. On the other hands, students also believe that leaving comments on their classmates' blogs were a fun activity. There is $10.00 \%$ of the students strongly agreed, $44.00 \%$ agreed and $21.00 \%$ not sure towards the statement.

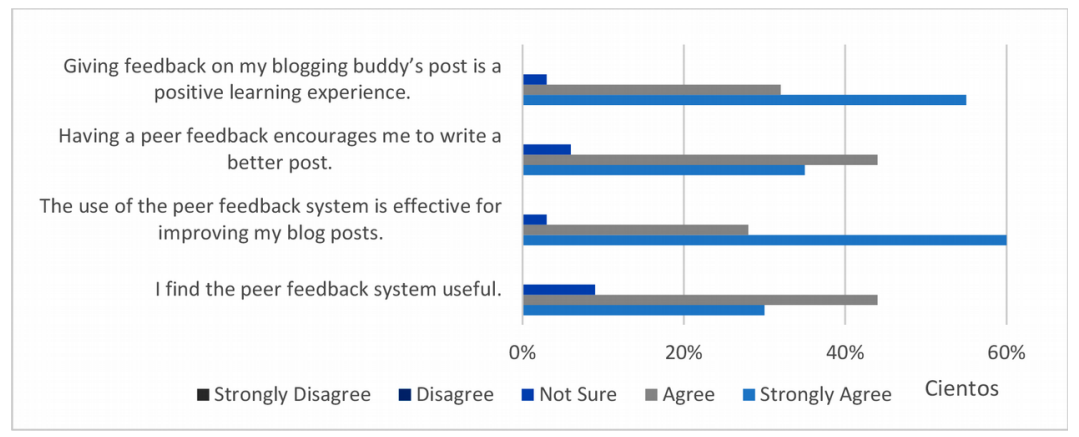

Figure 3. Students' perception on the use of peer feedback in Blog-Assisted Language Learning upon the process of improving writing skill

Based on the Figure 3 provided above, students believed that peer feedback was a helpful way to make the Blog-Assisted Language Learning more effective in improving their writing skills. Students realized that giving feedback to their pair is a very positive learning experience. There are $55.00 \%$ of the students strongly agreed to the statement, followed by $32.00 \%$ of them agreed and only $3.00 \%$ not sure. In addition, students believe that having a peer feedback activity encouraged them to write a better article in the blog. $35.00 \%$ of them strongly agreed, $44.00 \%$ agreed, and only $6 \%$ not sure towards the statement. Students also believe that the use of the peer feedback system was effective to improve their blog posts. $60.00 \%$ of the students strongly agreed to the statement, followed by $28.00 \%$ of them agreed and only $3.00 \%$ of them not sure. Last, students found that the peer feedback was useful for learning writing using blogging activity. $30.00 \%$ strongly agreed, $44.00 \%$ agreed and only $9.00 \%$ not sure regarding the statement.

\section{Discussion}

Referring to the objectives of this study is to investigate if the use of Blog-Assisted Language Learning significantly improve students' writing skill and their motivation in learning writing skill trough Ball. The results of this study proved that the use of Ball in improving writing skill and motivation were significantly increased. It can be seen that the scores obtained from both groups are significantly different. The scores can increase in the experimental group due to the process of teaching and learning takes place according to the planning has been targeted. Besides, this improvement due to the students can discuss with their friends via blog toward they write and discuss. They can check each other work for making sure that they have done their best accordingly. Learning collaboratively and using technology help students' skill and motivation (Muslem \& Abbas, 2017). In addition, the results of this study are in line with the previous studies that the use of digital technology and peer support improved students' outcome especially writing skill (Kim \& Bae, 2020).

Using ICT or digital technology is not only improved students' learning outcome but also improve teachers' way of teaching (Camelo, Torres, Reche \& Costa, 2018; Palacios-Hidalgo, Gómez-Parra \& Huertas-Abril, 2020). There are four benefits of learning writing through Blog-Assisted Language Learning. First, promotes autonomous learning by providing opportunities for students to take more control of their learning. Second, motivates students to become better readers and writers. Third, promotes discussion among students. Last, encourages the use of the Internet and the Web among 
students (and teachers) (Kung, 2018). The use of Blog-Assisted Language Learning enable students to interact and exchange between students to identify their preferences and even explore new subjects. Another positive aspect about blogging is that "if they know more people are reading and writing to them, that creates more engagement (Kung, 2018). Motivation is also essential in learning process. The appropriate media technology used is paramount. The right technology used can improve students' motivation in learning (Spector \& Park, 2017; Kung, 2018). Students agreed that BALL is a very fascinating methodology to be done in a writing class. The blogging activity including writing articles, commenting and doing peer feedbacks were found to be a motivating activity for improving writing skills.

It is the first time to use Ball in the teaching and learning process at the State Islamic University of Ar-Raniry, Banda Aceh, especially in improving writing skill. Therefore, this study has given an essential alternative strategy and media to improve writing skill at the English Education Department students. Therefore, this study have helped university students to improve their writing skill after they are taught by using Blog-Assisted Language Learning and as well as their motivation.

\section{Conclusion}

It cannot be denied that the presence of technology in the $21^{\text {st }}$ century to help students and teacher to upgrade their respective quality of learning outcome. Regarding to this current study can be concluded that the use of Blog-Assisted Language Learning improve students' writing skill and motivation. Therefore, teachers or lecturers who teach writing at the university to use Blog as the best alternative media of improving their students' writing skill and motivation. However, this current study has the limitation of course. This study involved non-native speaker as a result the authors should use students' native language even in a small portion. The students' need to understand well about the instruction that mentioned by the authors during the treatment. In addition, this study also has limitation on the connection with the internet when students were asked to send the email and blog from home since they had limited facilities. Therefore, further research should be conducted with all the facilities that support the process of teaching and learning can run smoothly and enjoyably.

\section{Acknowledgement}

The authors would like to express gratitude to Head of English Department and lecturers of the department of State Islamic University of Ar-Raniry, Banda Aceh, Indonesia for their endless support during this research.

\section{Declaration of Conflicting Interests}

The authors declared no potential conflicts of interest with respect to the research, authorship, and/or publication of this article.

\section{Funding}

The authors did not receive financial support. It is self-sponsored. 


\section{References}

Aditya, D.S. (2021). Embarking digital learning due to COVID-19: Are teachers ready? Journal of Technology and Science Education, 11(1), 104-116. https://doi.org/10.3926/jotse.1109

Ahluwalia G., Gupta D., \& Aggarwal D. (2011). The Use of Blog in English Language Learning: A Study of Student Perceptions. Profile, 13(2), 29-41.

Alfarwan, S. (2019). University Student Access to and Use of Electronic Devices: A Latent English Language Learning Potential. Teaching English with Technology, 19(1), 102-117.

Arslan, R.Ş., \& Şahin-Kızıl, A. (2010). How can the use of blog software facilitate the writing process of English language learners? Computer assisted language learning, 23(3), 183-197.

https://doi.org/10.1080/09588221.2010.486575

Ball, A.F. (1992). Cultural Preference and the Expository Writing of African-American Adolescents. Written Communication, 9(4), 501-532. https://doi.org/10.1177/0741088392009004003

Barnett, M.A. (1989). Writing as a Process. The French Review, 63(1), 31-44.

Camelo, G.E.H., Torres, J.M.T., Reche, M.P.C., \& Costa, R.S. (2018). Using and integration of ICT in a diverse educational context of Santander (Colombia). Journal of Technology and Science Education, 8(4), 254-267. https://doi.org/10.3926/jotse.314

Chhabra, R., \& Sharma, V. (2011). Applications of Blogging in Problem Based Learning. Educational Information and Technology, 18(3), 3-13. https://doi.org/10.1007/s10639-011-9168-6

Chinnery, G.M. (2006). Emerging technologies going to the MALL: Mobile assisted language learning. Language learning \& technology, 10(1), 9-16.

Cook, L.K., \& Mayer, R.E. (1988). Teaching Readers about the Structure of Scientific Text. Journal of Educational Psychology, 80(4), 448-456. https://doi.org/10.1037/0022-0663.80.4.448

Danaher, M., \& Schoepp, K. (2020). Effective assessment of workplace problem-solving in higher education. Journal of Information Technology Education: Research, 19, 1-16. Available at: https://www.informingscience.org/Publications/4496 https://doi.org/10.28945/4496

Dashtestani, R. (2018). Collaborative academic projects on social network sites to socialize EAP students into academic communities of practice. Teaching English with Technology, 18(2), 3-20.

Fatimah, A.S., \& Santiana, S. (2017). Teaching in 21st century: Students-teachers' perceptions of technology use in the classroom. Script Journal: Journal of Linguistic and English Teaching, 2(2), 125. https://doi.org/10.24903/sj.v2i2.132

Gardner, S., \& Birley, S. (2012). Blogging for Dummies (4th ed.). Hoboken, New Jersey: Wiley Publishing.

Getgood, S. (2010). Professional Blogging for Dummies. Indianapolis, Indiana: Wiley Publishing.

Goldstein, A.M. (2009). Blogging Evolution. Evolution Education and Outreach, 2, 548-599. https://doi.org/10.1007/s12052-009-0149-9

Honarzad, R., \& Rassaei, E. (2019). The Role of EFL Learners' Autonomy, Motivation and Self-efficacy in Using Technology-based Out-of-Class Language Learning Activities. The JALT CALL Journal, 15(3), 23-42. https://doi.org/10.29140/jaltcall.v15n3.170

Hourigan, T., \& Murray, L. (2010). Using blogs to help language students to develop reflective learning strategies: Towards a pedagogical framework. Australasian Journal of Educational Technology, 26(2). 209-225. https://doi.org/10.14742/ajet.1091

Information about Expository Writing (2018). Available at: http://www.umich.edu/ exppro/info.html 
Kim, G., \& Bae, J. (2020). A Study into Students' Use of Digital English Learning Strategies in Tertiary Education. Teaching English with Technology, 20(1), 21-42.

Kung, F.W. (2018). Assessing an innovative advanced academic writing course through blog-assisted language learning: Issues and resolutions. Innovations in Education and Teaching International, 55(3), 348-356. https://doi.org/10.1080/14703297.2015.1108213

Lankshear, C., \& Knobel, M. (2003). New literacies: Changing knowledge and classroom learning. Open University Press.

Lin, M.H., Groom, N., \& Lin, C.Y. (2013). Blog-assisted learning in the EFL writing Classroom: A Phenomenological Analysis. Educational Technology \& Society, 16(3), 130-139.

Muslem, A., \& Abbas, M. (2017). The Effectiveness of Immersive Multimedia Learning with Peer Support on English Speaking and Reading Aloud. International Journal of Instruction, 10(1), 203-218. https://doi.org/10.12973/iji.2017.10113a

Oliver, B., \& Goerke, V. (2007). Australian undergraduates' use and ownership of emerging technologies: Implications and opportunities for creating engaging learning experiences for the Net Generation. Australasian Journal of Educational Technology, 23(2). https://doi.org/10.14742/ajet.1263

Oravec, J.A. (2002). Bookmarking the world: Weblog applications in education. Journal of Adolescent \& Adult Literacy, 45(7), 616-621.

Palacios-Hidalgo, F.J., Gómez-Parra, M., \& Huertas-Abril, C.A. (2020). Digital and media competences: Key competences for EFL teachers. Teaching English with Technology, 20(1), 43-59.

https://doi.org/10.4018/IJWLTT.2020100101

Pinkman, K. (2005). Using blogs in the foreign language classroom: Encouraging learner independence. The Jalt CALL Journal, 1(1), 12-24. https://doi.org/10.29140/jaltcall.v1n2.r2

Qader, R.O., \& Yalcin-Arslan, F. (2019). The Effect of Flipped Classroom Instruction in Writing: A Case Study with Iraqi EFL Learners. Teaching English with Technology, 19(1), 36-55.

Richardson, W. (2009). Blogs, wikis, podcasts, and other powerful Web tools for classrooms (2nd ed.). Thousand Oaks, CA: Corwin Press.

Said, N.E.M., Yunus, M., Doring, L.K., Asmi, A., Aqilah, F., \& Li, L.K.S. (2013). Blogging to enhance writing skills: a survey of students' perception and attitude. Asian Social Science, 9(16), 95-101. https://doi.org/10.5539/ass.v9n16p95

Satriani, I., Emilia, E., \& Gunawan, M.H. (2012). Contextual Teaching and Learning Approach to Teaching Writing. A Journal of First and Second Language Teaching and Learning, 2(1), 10-22. https://doi.org/10.17509/ijal.v2i1.70

Sidek, E.A.R., \& Yunus, M.M. (2012). Students’ Experiences on using Blog as Learning Journals. Procedia - Social and Behavioral Sciences, 67, 135-143.

Smith, K., \& Mainka, C. (2010. Pedagogy and Learning Technology: A Practical Guide. Edinburgh: Edinburgh Napier University

Spector, J.M., \& Park, S.W. (2017). Motivation, learning, and technology: Embodied educational motivation. Routledge. https://doi.org/10.4324/9781315537641

Sun, Y.C. (2009). Voice blog: An exploratory study of language learning. Language Learning \& Technology, 13(2), 88-103.

Ward, J.M. (2004). Blog-assisted language learning (BALL): Push button publishing for the pupils. TEFL Web Journal, 3(1), 1-16. 
Wilder, H., \& Merritt, T. (2004). Weblogs in language arts instruction. In Society for Information Technology \& Teacher Education International Conference (3969-3973). Association for the Advancement of Computing in Education (AACE).

Wu, W.S. (2005). Using blogs in an EFL writing class. In Meeting of the 2005 Conference and Workshop on TEFL and Applied Linguistics (16, 426-432). Department of Applied English, Ming Chuan University.

Published by OmniaScience (www.omniascience.com)

Journal of Technology and Science Education, 2022 (www.jotse.org)

\section{(c) (1) (\$)}

Article's contents are provided on an Attribution-Non Commercial 4.0 Creative commons International License. Readers are allowed to copy, distribute and communicate article's contents, provided the author's and JOTSE journal's names are included. It must not be used for commercial purposes. To see the complete licence contents, please visit https://creativecommons.org/licenses/by-nc/4.0/. 